\title{
Inference and Relevance in Paul's Allegory of the Wild Olive Tree
}

\author{
P J Maartens \\ Department of Biblical Literature \\ University of Durban-Westville
}

\begin{abstract}
Relevance theory accounts for Paul's preference for 'the wild olive' tree in using horticultural practices of grafting to symbolise his mission to the Gentiles. The olive tree facilitates inclusive imagery. The principle of ostensive inferential communication also accounts for the violation of horticultural conventions. Relevance juxtaposes God who calls and Israel that fails. The remnant as cultivated olive is the balance of this process. Relevance 'roots' the symbolism in election and the covenant as origins of Israel. Israel obtains eschatological relevance and significance. Gentile Christians are drawn into eschatological Israel. The church is rooted in continuity with the historical Israel. The juxtaposition of different readings renders all interpretation relative. Yet, changing the cognitive environment of its readers guarantees the relevance of exegetical discourse.
\end{abstract}

\section{INTRODUCTION}

Relevance theory interprets inferential ostensive language communication in a discourse. Relevance theory takes its point of departure from the multi-interpretability of human communication. This article intends to illustrate the means of procuring communication consistent with the principle of relevance. An interpretation of a discourse is regarded to be 'relevant' when the meaning derived is provided by practice of the 'least processing effort' which is consistent with the principle of relevance. Relevance theory provides us with a pragmatic theory of discourse. Every new interpretation given to the text adds yet another dimension to our understanding of the meaning of text. The greater the multiplicity of meaning the greater the relevance of the text. It stands to reason that if these preliminary observations are true of ordinary language usage it will be even more true of metaphoric language usage in any given discourse.

* This article is adapted from a paper read at the International Meeting of the SBL held at Lausanne July, 1997. My participation in the proceedings of the meeting was partly facilitated by a grant of the Centre for Science Development of the Human Sciences Research Council, South Africa. The article is a sequel to the previous article entitled 'A Critical Dialogue of Structure and Reader in Romans 11:16-24 


\section{METHOD}

The expression 'Inference and Relevance', in the title of the thesis, suggests the use of recent linguistic theory to supplement the task of interpretation. Relevance theory is chosen because of its fundamental criticism of 'code theory' prevalent in current literary theory and interpretation. Formalism and structuralism are prime examples of 'code theories'. Relevance theory, however, does not render 'code theory' obsolete. It supplements alleged inadequacies of code theory in semiotics. Relevance theory supplements semiotic analysis because of the following alleged inadequacies inherent to code theory ${ }^{2}$ :

The gap between the semantic representation of the sentence ${ }^{3}$ and the meaning of the sentence cannot be narrowed by more coding but only by application of the principle of relevance. This criticism of 'relevance theory' levelled against 'code theory' places subject/object relations at the root of problems. Both semiotics, inclusive of formalism and structuralism, and relevance theory address the subject/object relations in language and text communication. Semiotics attempts to close the gap between the sign and its significance by decoding the message of the text. Formalism attempts to close this gap by making deautomatised language usage, the study object of literary theory. Sperber and Wilson (1986:9) maintain that the gap between the semantic representation of sentences and the thoughts they communicate cannot be filled by more coding but only by inference.

In view of the reasons stated above, it has become necessary to find a more convincing method of interpretation. From the outset it should be reiterated that relevance theory does not reject or diametrically oppose code theory. Rather, it attempts to achieve relevance by fulfilling the structure of coded language communication. Relevance is achieved by completion of the communication process. Sperber and Wilson (1986:3, 14-15) make it very clear that relevance theory slots into code theories and supplements them. We are also not left with a choice between the two methods. Sperber and Wilson clearly state that 'both the code model and the inferential model can contribute to the study of verbal communication' (p. 3). Although relevance theory is not a semiotic theory per se, we find it most appropriate to term the application of relevance in literary texts 'inferential semiotics'. This thesis applies the principles of inferential semiotics to reading the text of $\mathrm{Rm} 11: 16-24$. It now remains to be said how relevance theory or inferential semiotics intends to supplement historical semiotics. 


\section{The Principles of Relevance}

The theory of relevance is a theory of communication and cognition developed in the wake of Grice's critique of the 'code theories' common to most communication frameworks. The theory of relevance, as proposed by Sperber and Wilson (1986), signifies the beginning of a return to the praginatics in semiotics. This proposal comes at the peak of an era marked by high technological communication systems in the mass media. This is also an era characterised by decisive global negotiations and dialogue, that is the East/West nuclear arms negotiations, Arab/Israeli talks and political settlements in Africa and elsewhere. The theory is grounded in a general view of human cognition. Sperber and Wilson maintain that cognitive processes are geared to achieving the greatest possible cognitive effect for the smallest possible processing effort.

The changed historical conditions of the contemporary era offer the exegete a new opportunity to close the gap between the representation of sentences and the meaning of the text. Relevance theory addresses numerous shortcomings of 'code theories' in semiotics. The most important critique of relevance theory may be summarised in the following points:

* One of the major shortcomings detected in 'code theories' is that no account is given of non-linguistic properties such as the time and place of utterance, the identity of the speaker and the speaker's intentions, affecting the cognition of utterances. Sperber and Wilson (1986:10) supplement the interpretation of utterances by drawing on criteria established in the field of pragmatics, especially the pragmatics of Grice (1975 and 1978) and Searle (1980). To fill the gaps in communication between the semantic representation of the sentence and the intention of the utterance, relevance theory adds an extra pragmatic level of decoding to the linguistic level provided by the context. The extra pragmatic level of decoding may be recognized and comprehended by an inferential process. The inferential process strengthens and draws on the encyclopedic knowledge of the text. Relevance follows in the wake of inference which fulfils the intentions of the communicator.

* Relevance becomes manifest in ostensive-inferential communication. Relevance theory challenges the exegete to read his or her text again within an 'ostensiveinferential communication' framework. 'Ostension' means for Sperber and Wilson (1986:49) behaviour 'which makes manifest an intention to make something manifest. Showing someone something is a case of ostension'. The 'communicator' in relevance theory is the author of the written text, which of course includes 
Tertius as Paul's amanuensis. Assuming that the structure of, for example Romans 5:1-11 is 'ostensive', it becomes necessary to determine the relevance of what the structure communicates. Ostensive communication comes with a tacit guarantee of relevance (Sperber \& Wilson 1986:49). Sperber \& Wilson (1986:54) equate ostension and inferential communication: Inferential communication and ostension are one and the same process, but seen from two different points of view: that of the communicator who is involved in ostension and that of the audience who is involved in inference.

* Relevance to the individual is achieved when the communicator's intentions are fulfilled. The ostensive processing of new information which gives rise to a multiplication effect is what Sperber and Wilson (1986:48) call relevant information: 'The greater the multiplication effect, the greater the relevance', Relevance theory relates the communicator's intention to the recognition of that intention by the recipient. Sperber and Wilson continue to say that 'the recognition of the informative intention will itself lead to the fulfilment of that intention, so that as a result of an act of communication, both the communicative and the informative intention will be fulfilled'. The fourth point which follows is concerned with the changing of the cognitive environment ${ }^{4}$ of the reader.

* The fulfilment of the communicative intentions changes the cognitive environment of the recipient. As Sperber \& Wilson $(1986: 48,71,103)$ indicate ostensive communication is relevant to an audience when it improves their overall representation of the world and thus changes their cognitive environment. The greater the contextual effect on the cognitive environment of the addressee, the greater the relevance of communication. Relevance theory thus also articulates the communication processes in reception aesthetics. Relevance theory is compatible with reception aesthetics because changing of the recipient's cognitive environment, by improving recipients' overall representation of the world, is yet another way of constituting an aesthetic object for the artifact. In both cases relevance is achieved by fulfilling the communicator's intentions or the structure of the text.

* Closely associated with communicative intentions is the notion of the use of language as speech-acts. Speech-act theory is significant for persuasive discourse encountered in classical diatribe. Speech-act theory maintains the illocutionary and perlocutionary ability of language to perform actions. Searle (1979) distinguished the following speech-acts: 
- assertives, which commit the speaker to the truth of the assumption expressed;

- directives, which attempt to get the hearer to do something;

- commisives, which commit the speaker to the performance of a future action;

- expressives, which convey the speaker's emotional attitude to the assumption expressed; and

- declarations, which bring about the state of affairs described in the assumption expressed.

* Sperber and Wilson (1986:244) view speech-act theory as a natural complement to Gricean pragmatics, which distinguishes between contextual explicatures and implicatures. They further distinguish declarative, interrogative, imperative, requestive and advisory speech-acts. All forms of speech-act are relevant for Paul's use of classical diatribe.

Relevance theory contributes to speech-act theory the recognition that the speaker should ostensively communicate the intention to effect some attributed or desirable state of affairs. Specifying the relevance of speech-act theory can be illustrated with reference to requestive or advisory speech-acts. According to Sperber \& Wilson (1986:250), a requestive speech-act is one that represents a certain state of affairs as desirable from the speaker's point of view. An advisory speech-act is one that represents a certain state of affairs as desirable from the hearer's point of view. The question from whose point of view the state of affair's is desirable should be answered by the hearer on the basis of inferences. The principle of relevance provides a means of distinguishing from whose point of view a particular state of affairs is desirable. The principle of relevance decides this question on the basis of inferences drawn from the communicator's informative intention. The illocutionary force indicators such as 'declarative or imperative mood or interrogative word order merely have to make manifest a rather abstract property of the speaker's informative intention: the direction in which the relevance of the utterance is to be sought'.

* Foregrounding as an information-processing device contributes to relevance. All stages of foregrounding contribute to relevance by virtue of the fact that all communicated information, as Sperber and Wilson (1986:V11) maintain, comes with a guarantee of relevance. Relevance is that single property which makes information worth processing. 
Relevance tallies with efficiency. Efficiency consists in reaching the goals of information-processing at minimal cost. Relevance consists in the processing of such information which is set to achieve the greatest possible cognitive effect for the smallest possible processing effort. Let us consider the relevance of the main devices of foregrounding for the interpretation of a text:

The first stage of foregrounding to be considered is syntagmatic foregrounding as extra patterning. Relevance theory regards extra patterning as a reinforcement of the hearer's 'natural tendency to reduce processing effort by looking for matching parallelisms in propositional form and implicature' (Sperber and Wilson 1986: 222). Levin's (1969:33) coupling will contribute to relevance by minimizing the processing effort of Jakobson's parallelism. Sperber and Wilson (1986:222) continue: 'A speaker aiming at optimal relevance would deliberately introduce such linguistic parallelisms only if she expected them to lead to a reduction in the hearer's processing effort, and in particular if she thought that the search for parallel contexts and contextual effects would be rewarded'. Consider the following parallels:

$\mathrm{Rm}$ 8:30S 297 And those whom he predestined he also called

S 298 and those whom he called he also justified

S 299 and those whom he justified he also glorified.

Sentences 297-299 are three parallels in a rhetorical climax. A climax is a 'logical entry' determined by a set of rules such as:

- The relative pronouns, verbs and articles are coupled in syntagmatic equivalent positions.

- The final verb (or noun) repeats in an initial position in the subsequent sentence.

- The parallel sentences combine in a causal relation to one another.

Sperber and Wilson (1986:86) contend that 'The logical entry for a concept consists of a set of deductive rules which apply to logical forms of which that concept is a constituent'. A climax is consequently a logical entry in deductive rules. It is also more than that. 
The three parallels also constitute an encyclopedic entry. The encyclopedic entry contains information about the extension and /or denotation of the concept: that is, about the objects, events and/or properties which instantiate it. The encyclopedic entry denoted by the three parallels is the suffering righteous one/servant. The verbs coupled in a causal relationship to one another denote the event of suffering righteousness. These verbs are: 'he foreknew', 'he predestined', 'he called', 'he justified' and 'he glorified'. The relation between the various assumptions of these verbs is what Sperber and Wilson (1986:84) terms a 'relation of entailment'. The parallel strophes of the climax entail the suffering righteous one/servant. Confirmation of this interpretation may be sought in a context in which all three clauses have parallel contextual effects. $\mathrm{Rm}$ 8:29 provides such a context:

- For those whom he foreknew he also predestined to be conformed to the image of his Son, in order that he might be the first born within a large family (NRSV).

Parallelisms reduce the processing effort in text communication. According to Sperber and Wilson (1986:224), a strategy such as paralielism 'takes the hearer beyond standard contexts and premises, and yields typical poetic effects'. How do poetic effects affect the mutual cognitive environment of the speaker and the hearer? They marginally increase the manifestness of a great many weakly manifest assumptions. Paul knew this set of assumptions. The readers knew this set of assumptions. The wide array of cognitive effects achieve relevance by changing their mutual cognitive environment. The hearers change their representation of the world. They identify themselves with 'the righteous one'. Romans 8:28 confirms: 'We know that all things work together for good for those who love God, who are called according to his purpose'. The faithful whom he foreknew, 'he predestined to be conformed to the image of his Son... and those whom he predestined he also called; and those whom he called he also justified; and those whom he justified he also glorified'. Paul and the congregation are mutually conscious of their calling and glorification. Parallelism contributes to relevance in the following way:

- by reducing the processing effort;

- by directly contrasting implications; and

- by increasing the manifestness of a great many weakly manifest assumptions. 
Sperber \& Wilson (1986:224) conclude that poetic effects result from the accessing of a large array of very weak implicatures in the ordinary pursuit of relevance. Stylistic differences are just differences in the way relevance is achieved. The positive contribution which relevance theory makes to analyses of 'code theories' is the recognition that stylistic devices contribute to relevance a powerful means of changing the cognitive environment of the reader and consequently the reader's representation of the world.

* In relevance theory metaphor involves an interpretive relation between the propositional form of an utterance and the thought it represents. The relation between the propositional utterance and the thought expressed is one of resemblance as opposed to literalness or identity. The approach of resemblance combined with relevance provides an adequate account of a live poetic metaphor.

Sperber \& Wilson (1986:233) concern themselves with resemblance of a very restricted type, which they term 'logical resemblance among propositional forms'. Two propositional forms resemble one another if they share the same logical properties. Relevance theory contributes to the identification of these resemblances in the interaction theory of metaphor.

Metaphor is an interpretative expression of the speaker's thought and not a literal one. A literal utterance has the same propositional form of the thought which it represents. A metaphorical expression is an utterance which shares some, but not all, of the logical properties of that propositional form which it represents. In the use of metaphorical language the speaker is presumed to aim at optimal relevance, not at literal truth. Sperber \& Wilson (1986:233) view the function of the metaphor as follows: 'The optimal interpretive expression of a thought should give the hearer information about the thought which is relevant enough to be worth processing, and should require as little processing effort as possible'. The principle of relevance applies when the effort needed in processing the utterance is outweighed by the gain in the information acquired in the process. A metaphoric expression is optimally relevant where the effort to process it is offset by the gain in information which the imagery conveys.

The filter of the metaphor is constituted by the principle of relevance. Sperber \& Wilson (1986:234) maintain that 'the principle of relevance provides a means of distinguishing those contextual implications which are shared from those which are not; that is, it gives you a way of constructing the right interpretive assumption about the speakers' 'informative intention'. If the metaphor is successful, the hearer has to 'start computing ... those implications which are relevant to him, and continue to add them 
to the overall interpretation of the utterance until it is relevant enough to be consistent with the principle of relevance'. The reader applies the principle of relevance to the retopicalising of semantic features of the vehicle which she/he transfers to the tenor of the metaphor. This may happen because, as Sperber \& Wilson (1986:235) note 'the hearer can proceed on the assumption that these two propositional forms have identifiable logical and contextual implications'. In the famous example which Black (1962:421) provides: 'man is a wolf', contextual and semantic features (treacherous) (alarming) and (hateful) have been processed to implicate 'man' as tenor of the vehicle. However, as Sperber \& Wilson (1986:236) indicate, the speaker must have intended something more than the mere features of (hatefulness) (treacherousness) and (alarming) attributed to the character of the person, if the relative indirectness of the utterance is to be justified. The speaker wanted to say more than could be conveyed by the statement: 'Man is an alarming, hateful and treacherous character'. The speaker might also have had the idea that man can be (vicious) (voracious) and (harmful); therefore, in short: 'man is a wolf'. Provided the reader has re-topicalised an 'acceptable range of implications' ( $p$ 234), she/he will have achieved optimal relevance. Optimal relevance is achieved when the contextual effects and contextual implications outweigh the processing effort.

In this article the contextual effects of metaphoric language will be written in the notational conventions of parentheses () as proposed by Katz (1972). Compiling such a set of semantic features, in the process of articulating metaphoric language, creates an awareness that such a set of semantic features can be infinite. This is true because metaphoric language is our mirror into reality. Besides, metaphor is a polymorphous figure of speech. This critical awareness is mostly true because the speaker weakly implicates contextual effects of the metaphor. Sperber \& Wilson (1986:236) continue to explain: 'A good creative metaphor is precisely one in which a variety of contextual effects can be retained and understood as weakly implicated by the speaker'. The wider the range of potential implicatures, the greater the readers responsibility to reconstruct them. The greater the hearer's responsibility for constructing contextual effects, articulated by semantic features, 'the more poetic the effect'. Sperber \& Wilson (1986: 236) add 'the more poetic the effect, the more creative the metaphor'. The art of metaphor lies in reducing a wide array of contextual effects and implications to a single expression, simile, allegory or parable. Sperber \& Wilson (1986:237) conclude:

The surprise or beauty of a successful creative metaphor lies in this condensation, in the fact that a single expression which has itself been loosely used will determine a very wide range of acceptable weak implicatures. 
These principles will suffice to illustrate the significance of relevance theory for the interpretation of a text and particularly metaphoric language usage. Subsequently we apply these principles to a reading of $\mathrm{Rm} 11: 16-24$.

\section{The Text}

Romans 11:16-24 will begin with sentence 399 and extend to sentence 414 . The sentences may be specified as follows:

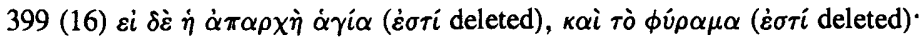

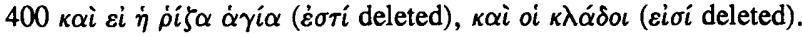

401.1 (17) Ei $\delta \dot{\varepsilon} \tau i \nu \varepsilon \varsigma \tau \hat{\omega} \nu \kappa \lambda \alpha \dot{\alpha} \delta \omega \nu \dot{\varepsilon} \xi \varepsilon \kappa \lambda \alpha \dot{\alpha} \sigma \theta \eta \sigma \alpha \nu$,

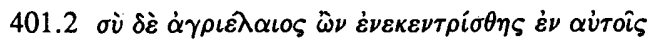

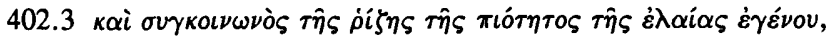

401 (18) $\mu \grave{\eta} \kappa \alpha \tau \alpha \kappa \alpha \nu \chi \hat{\omega} \tau \hat{\omega} \nu \kappa \lambda \alpha \dot{\alpha} \delta \nu^{\circ}$

402 ( $\gamma \iota \nu \dot{\omega} \sigma \kappa \varepsilon \tau \varepsilon$ ö $\tau \iota$ deleted)

402.1 вi $\delta \grave{\varepsilon} \kappa \alpha \tau \alpha \kappa \alpha v \chi \hat{\alpha} \sigma \alpha \iota$

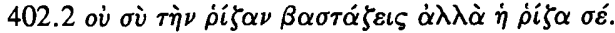

403 (19) غ่ $\dot{\rho} \varepsilon \hat{i} \varsigma$ oùv,

$403.1{ }^{\prime} \mathrm{E} \xi \varepsilon \kappa \lambda \dot{\alpha} \sigma \theta \eta \sigma \alpha \nu \kappa \lambda \dot{\alpha} \delta o \iota$

403.1.1 ¿ $\nu \alpha \dot{\varepsilon} \gamma \grave{\omega} \dot{\varepsilon} \gamma \kappa \varepsilon \nu \tau \rho \iota \sigma \theta \hat{\omega}$.

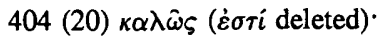

$405 \tau \hat{\eta} \dot{\alpha} \pi \iota \sigma \tau i \underline{\alpha} \dot{\varepsilon} \xi \varepsilon \kappa \lambda \dot{\alpha} \sigma \theta \eta \sigma \alpha \nu$,

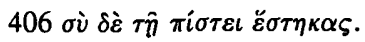

$407 \mu \grave{\eta} \dot{v} \psi \eta \lambda \grave{\alpha} \phi \rho o ́ v \varepsilon \varepsilon$

$408 \dot{\alpha} \lambda \lambda \dot{\alpha} \phi o \beta \circ \hat{v}$.

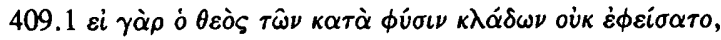

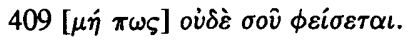

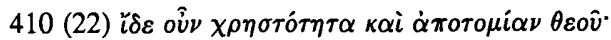

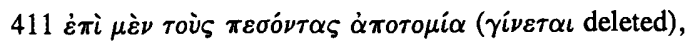

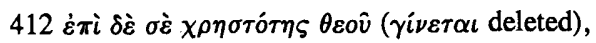

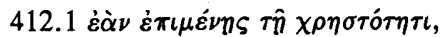

$412.2 \dot{\varepsilon} \pi \varepsilon \grave{~} \kappa \alpha \grave{~} \sigma \grave{\varepsilon} \dot{\varepsilon} \kappa \kappa o \pi \dot{\eta} \sigma \eta$.

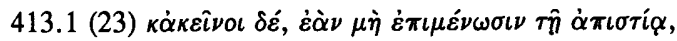

$413 \dot{\varepsilon} \gamma \kappa \varepsilon \nu \tau \rho \iota \sigma \theta \dot{\eta} \sigma o \nu \tau \alpha \iota^{\circ}$

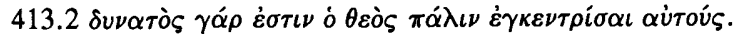

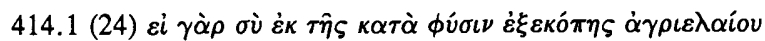

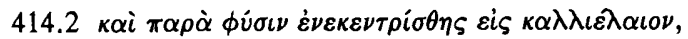

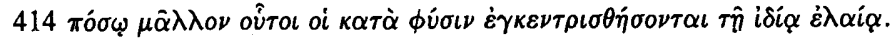




\section{A RELEVANCE ANALYSIS OF ROMANS 11:16-24}

\subsection{The Releyance of Preceding contexts}

The preceding context Romans 9:1-11:15 contributes significantly to our understanding of Romans 11:16-24. The preceding context provides a framework in which Paul's allegory of the wild olive becomes ostensive and inferential. 'Preceding context(s)' may be explained as assumptions or premises alluded to which are modified by subsequent ostensive inferential references in a given text. Romans 1:17 may be considered to be a preceding context of Romans 3:19-26. The latter in turn is a preceding context of Romans 5:1-11. Ostensive inferential references modify previous premises or assumptions in the text. Previous contexts are constantly modified by ostensive inferential references which may subsequently correlate with or even contrast them. The following themes in $\mathrm{Rm}$ 9:1-11:15 counter-determines the allegory of Romans 11:16-24.

\subsubsection{Covenant Promises}

An underlying theme which unites Romans 9-11 is, $\dot{\varepsilon} \pi \alpha \gamma \gamma \varepsilon \lambda i \alpha_{i}$ promises of Yahweh. Romans 9:6 maintains that the word of God never failed ( $\dot{\varepsilon} \kappa \pi \dot{\varepsilon} \pi \tau \omega \kappa \varepsilon \nu$ ) its promises. The promises prevailed throughout the patriarchal history of Abraham with Sarah (Rm 9:8), Isaac with Rebecca (Rm 9:10) and Jacob. The nouns Abraham, Sarah, Isaac, Rebecca and Jacob are, via the promises, prototypes of the faithful community. The promises articulate the divine intervention which cietermines the destiny of faithful humanity. Israel, Dinkler (1956:115) maintains, is not cut off from God. Dinkler sees a contrast between Romans 9:6-13 and 11:1-32. In chapter 9 Paul deals with the fact that Israel 'stumbled over the stumbling stone' (Rm 9:32) and rejected the grace of God by reinterpreting the notion of Israel. God remains faithful to his covenant elected people. Paul asserts in Romans 9:6 'For not all Israelites belong to Israel and, and not all of Abrahams children are his true descendants'. It is not the children of the flesh but 'children of the promise' that are counted as descendants. In chapter 9 Paul solves the problem by giving an eschatological understanding to Israel. This interpretation will be further discussed in the relevance analysis of the allegory of the wild olive shoot.

Campbell (1981:34) believes God's promises are still valid for Israel and that she still serves his purpose even in her disobedience. Aageson (1986:268) sees a concretization of the promises in the Messiah born according to the promises of the prophets and belonging to the elect people of God. The promises provide consistency 
and continuity in the transition from the law to the Gospel of righteousness by faith. The privileges of the covenant remain in force. God called Israel into communion with Yahweh. Campbell (1981:31) comments that Paul regards Israel as the historical people of God to whom the promises were given. Yahweh is their God and they are Gods' people.

The promise of God causes division. Aageson (1986:269) draws our attention to the distinction which the promises draw between 'children of the flesh' and 'children of the promise'. God's call comes in freedom and sovereignty. Romans 9:14 asserts: 'I will have mercy on whom I have mercy, and I will have compassion on whom I have compassion'. Campbell (1981:28) comments that God's electing purpose '... is determined only by the freedom of divine choice'. Campbell continues to show that the argument of Paul in Romans 9 suggests the opening up of the covenant promises to include the Gentiles also. This promise Paul maintains in Romans 9:33 and 10:11 will not disappoint the one who believes. He reiterates his former position in Romans 5:5 that hope does not disappoint the faithful. Chapter 9 contrasts the themes of God that promises and Israel that fails.

\subsubsection{The Failure of Historical Israel}

The disobedience of historical Israel contrasts the faithfulness of Yahweh. Historical Israel is Israel as opposed to the eschatological Israel. Paul states in Romans 9:6 'not all israelites truly belong to Israel, and not all of Abraham's children are his true descendants'. Aageson (1986:267) interprets Romans 9-11 as literary result of a theological enterprise in which Paul seeks to address the problem of Israel's unbelief. Paul's anxiety for his people is compounded by theological incongruity and the religious dislocation caused by the Jewish rejection of the Gospel. Judaism stumbled over the stumbling stone ( $\mathrm{Rm}$ 9:32). She rejected righteousness through faith and excluded herself from the grace of God. Paul refers to a lack of understanding in Judaism Romans 10:3 and 19. Romans 10:3 claims that Israel sought to establish their own righteousness and refused to submit to divine righteousness by faith. She also failed to achieve righteousness by works of the law. Her conduct is tantamount to disobedience Romans 10:21 and 11:11-12 and 31. Ironically, the unfaithfulness of historical Israel aligns her with Esau in Romans 9:13 and Pharaoh her foe in Romans 9:17.

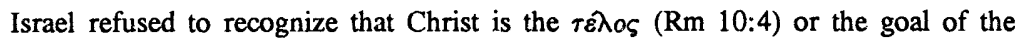
law. Getty (1988:466) explains $\tau \varepsilon \lambda{ }^{\circ}$ s as fulfilment of the law so that there may be righteousness for everyone who believes. It is mostly Calvinist interpreters, as Jewett (1985:351) shows, that regard $\tau \varepsilon \lambda \circ \varsigma_{\text {as }}$ 'fulfilment' or 'goal' of the law. Romans 11:2 asserts in contrast to the conduct of Israel that God has not rejected his people. In 
Romans 9-11 Paul calculates the cost of rejecting God's grace. Getty (1989:457) observes that it was primarily the Gentile mission which shaped the message of Paul. An implication of this assertion of Getty is the fact that Paul broadened his understanding of Israel to include the Gentiles without nullifying the fundamentals of Israel's theology. The Gospel went to the Gentiles because Israel of old failed dismally. Gaston (1982:418) summarises that it was primarily the Gospel of unmerited grace, the Gentile mission and the Gentile inclusion that Judaism rejected.

\subsubsection{The Continuity of Israel}

The correlation of the divine call and submission to righteousness by faith secures the continuity of Israel. The future of Israel is secured by the faithfulness of God to the promises of the covenant. Getty (1988:466) comments the success of the mission does not mean that Israel has been abandoned. Paul emphatically insists that God has not rejected Israel. In Romans 9:6 Paul asserts: 'It is not as if the word of God had failed'. God guarantees the future of Israel 'for the gifts and the calling of God are

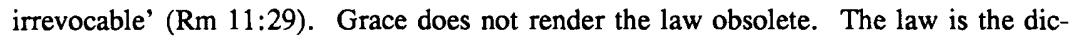
tionary of Grace. Romans 10:4 does not abolish the law. It is mostly Lutheran scholars, like Käsemann (1980:282), that interpret the expression: 'Christ is the end of the law' as a termination of the law. Aageson (1987:55) maintains there is no suggestion in Romans 9:6-13 that Paul understood the Christian community as having suspended Israel. He argues that the Christian community is 'the embodiment of Israel'. It is the Jewish notion of righteousness by works which Paul nullifies in point 2 above. Israel, however, does not remain the same. The 'composition' of Israel changes. Romans $11: 25 \mathrm{c}$ reads: 'a hardening has come upon part of Israel, until the full number of the Gentiles has come in. And so all Israel will be saved'. Getty (1988:468) adds 'There are two fundamental ideas that Paul cannot give up and which he tries to reconcile that Israel is God's people and that the Gentiles have been included in the plan of God for universal salvation'.

\subsubsection{A Theodicy}

The remnant is the remainder which the Jewish rejection of God's grace impose on Israel. The Jewish rejection makes the promises of God reach out to the Gentiles. The privileges of the covenant pass on to the nations. God is not a respecter of persons ( $R m$ 9:24). The elect embrace all who do not reject the call of God. The grace of God is impartial to Jew and Greek alike. The seven thousand who did not bow the knee to Baal re-echoes in Romans 11:4. Paul asserts 'so at the present time there is a remnant, 
chosen by grace'. Paul uses deuteronomistic historiography to designate the elect as remnant. Aageson (1987:57) strongly emphasises the point that the remnant has been elected and is preserved by grace and not by works of the law. The remnant makes the love of God evident. God cares. God does not leave Israel to her own devices. The new Israel which results from the election is the future servant of Yahweh. Getty (1988:466) comments that the notion of remnant in Romans 9:27 and 11:5 is a symbol of hope, not of disappointment or despair. Getty continues to explain that Paul's christology here is within the context of his theodicy, which aims to include the Gentiles even at the expense of the Jews. Post exilic deuteronomistic historiography counter-determines the future of Israel in Romans 9:25-26.

Those who were not my people I will call 'my people', and her who was not beloved I will call 'beloved'. And in the very place where it was said to them, 'You are not my people', there they shall be called 'children of the living God'.

Metaphoric terms such as 'my people', 'beloved', 'children of the living God' are determined by Paul's use of post-exilic deuteronomistic historiography. These metaphoric terms are reminiscent of post-exilic remnant theology. Getty (1988:467) rightly observes that Gentiles have hitherto been excluded from Israel but now are being included through the Gospel. The imagery goes even further than that. He uses the metaphors in violation of conventions of Jewish exclusivity. The remnant in post-exilic Jewish conventions refers exclusively to the remainder of believers faithful to the covenant. Paul's remnant theology is a complete reversal of Jewish values determined by their purity maps of people. Paul portrays Gentile Christians inclusively as the 'remnant of Yahweh'. They are not given exalted status by any Gentile standards. Paul's remnant metaphors confer upon them the calling of 'the servant of Yahweh'. Campbell (1981:32) observes that designations such as 'people of God' and 'children of the living God' are characteristics of the servant of Yahweh. The characteristics which Jewish Christians and Gentile Christians share are characteristic features of suffering righteousness.

\subsection{A Jewish and Gentile Christian Conflict}

Conflict is the primary historical condition which gives rise to imagery of suffering righteousness such as the allegory of the wild olive tree in Rm 11:16-24. In the Old Testament the history of the literary tradition of suffering righteousness is a history of 
the conflict of Judaism. Fine examples may be found in the patriarchal history, the song of Moses in Deut 32, Psalms of suffering righteousness of which Ps 56 is a prime example, the exile and Is $\mathbf{5 3}$ and deuteronomistic historiography in Inter-testamental literature. Ps 56 will suffice to show the Yahweh/servant relation encountered by the foe. The Psalm is marked by antitheses in the structure of the discourse. In verses 1a and $2 \mathrm{~b}$ (also verse 5 and 6 ) a relationship of hostility which exists between a foe and the servant/worshipper is contrasted:

1 'Be gracious to me, O God, for people trample on me;

all day long the foes oppress me; ...

6 They stir up strife, they lurk, they watch my steps.

As they hoped to have my life, ...'

The hostile threats of the enemy become apparent in this relationship. In verses 1a, 3$4,7,9 \mathrm{~b}-12$ the worshipper's relation to Yahweh antithetically contrasts the hostility of the enemy.

1a 'O God be gracious to me....

2c O Most high, 3 when I am afraid;

I put my trust in you...

4 In God whose word I praise, in God I trust; I am not afraid; what can flesh do to me?...

9 Then my enemies will retreat on the day when I call. This I know, that God is for me.

Yahweh remains faithful to his servant and covenant. He averts the danger. The servant is justified by his faith and redeemed. God glorifies him and bestows honour upon him. The expression: 'God is for me' echoes again in Psalm 118:6 which also Paul quotes in Romans 8:31. In Psalm 118:6 the author uses warrior imagery to portray the triumph of God's grace. God by grace reverses conditions of humiliation imposed on the servant. He averts the danger. The servant is justified by his faith and redeemed.

In the Christian communities of Rome this conflict was constituted by various interest groups. The conflict at Rome was probably one which Fink (1968:438) would 
term as a conflict of 'incompatible interests'. For Jewish Christians this conflict was a conflict of values based on the notion of Israel's priority. The privileges of this notion are articulated in Romans 9:3-5. Walters (1993:77) quotes Romans 1:16 which reads the Gospel is 'the power of God for salvation to every one who has faith, to the Jew first and also to the Greek'. Romans 2:9 and 10 contain similar statements. Early Christian worship centred around the synagogue. Some Gentile Christians confronted the notion of Israel's priority with the idea that God rejected Israel ( $R m$ 11:1). This constituted a conflict of incompatible interests.

Lenski (1966:42) suggests that societies, like individuals, are basically self-seeking units. The social interest of society are compromised by honour and shame and, according to Lenski (1966:42), power and authority. Campbell (1981:39) suggests that the group of Jewish Christians or Jewish-influenced god-fearers may have needed Paul's protection. His protection was required against the arrogance of the stronger Gentile party. The boasting of the Gentile Christian party suggests they were numerically and theologically possibly in ascendency. The conflict in Romans is primarily a conflict of Jewish priority verses Gentile ascendency. Walters (1993:79) argues convincingly that Jewish Christians were under unique pressure as the Christians. Jewish communities increasingly defined themselves in contrast to and even conflict with one another. After the banning order of Claudius was revoked, the Jews and Christians returned to Rome. During and after this time the Jews and Christians begun moving apart. Walters (1993:66) shows that as these communities drifted further apart, Jewish Christians found themselves under increasing pressure from both sides.

\subsection{Election Privileges}

Romans 9:1-5, according to Dinkler (1956:114), articulates attributes characteristic of Israel as the servant of God:

4 They are Israelites, and to them belong the adoption, the glory, the covenants, the giving of the law, the worship, and the promises ...

Campbell (1981:28) refers to these attributes as 'election privileges'. The expression 'election privileges' appears to be less problematic than the expression 'prerogative of salvation'. Israel never had any prerogative to salvation. Dinkler (1956:114) further comments that Paul does not attribute these characteristics to empirical-historical Israel but to the eschatological Israel. Eschatological Israel is the remnant of Yahweh. The inclusive language of Paul distributes these privileges to the Gentile Christian communities. The Christian communities are thus, on the one hand, rooted in the remnant 
and the promises of the servant. On the other hand, as Dinkler continues to show, eschatological Israel is interpreted in soteriological terms. The distribution of 'election privileges' to the Christian communities is facilitated by the continuity between faithful Christian communities and eschatological Israel. The distribution of election responsibilities is also evident in a reversal of status and values: Once God used Israel to convey the history of divine revelation to the nations but because Israel has become disobedient, God will use the Gentiles, as servants, to persuade Israel to adhere to the Gospel of 'faith by grace' only. For Paul the rejection of Jesus brought Judaism to shame. The honour of the covenant will, however, be restored by faithfulness of eschatological Israel.

The allegory of the wild olive tree is an ostensive inferential modification of the above contexts. The following analysis attempts to articulate the manner the imagery of the wild olive contrasts and modifies the context of Romans 9-11.

\subsection{Relevance and Inference in Romans 11:16-24}

Romans 11:16-24 reveals a highly structured text. Paul's use of diatribe contributes to relevance by changing the cognitive environment of the reader. His imagery becomes 'ostensively inferential' by applying characteristics of remnant theology to the Gentile mission. Paul interprets the church as 'remnant' in language of deuteronomistic historiography. Judaism may have fallen into a state of dishonour and disrepute. Yet, the Gentile mission will restore the honour of Israel. Until such time Paul's diatribe persuades the Gentiles not to be boastful. They should be faithful to their calling as servants of God. One notices the ostensive inferential character of Paul's language of the wild olive when one considers the manner in which characteristics of the 'remnant of Yahweh' is transferred to the Gentile mission. The illocutionary force of language persuades the reader of his/her share in the call of God to righteousness. The 'righteous one/servant' unfolds as a submerged metaphor in the allegory. The unit comprises of two parts.

The first part roots the righteous one in faithfulness to the divine promise or calling.

The second part contrasts the grace and severity of God.

The first major subject juxtaposes two cluster metaphors. The one cluster will be composed by a weak array of implicatures focusing on the image of the 'wild olive shoot'. The second cluster of metaphors will centre on an array of weak implicatures composing the imagery of the 'cultivated olive'. Consistent with the principle of relevance Paul 
metaphorizes the imagery. The metaphorizing of the imagery is clear from the tension between the imagery and the counter-determining context. Paul metaphorizes some constituents by violating general horticultural practices. Horticultural conventions graft the 'cultivated shoot' onto a 'wild root'. Consistent with the principle of relevance, Paul's infringement of this horticultural convention metaphorizes some verbs and nouns in the text. The 'wild olive shoot' is an interpretive metaphor in relevance theory. The interpretive metaphor establishes, according to Sperber \& Wilson (1986:230), a relationship of resemblance. An interpretive metaphor begins with a 'propositional form' which is an interpretation of the 'thought of the speaker'. Such an 'interpretation' may express (a), an 'attributed thought' and (b), a 'desirable thought'. Let us begin with the 'attributed thought'.

\subsubsection{The Attributive Thought}

Verse 16 contains two parallel propositions: 'If the first-fruit is holy, then also the lump'. In sentence 399 the verb غ̇бi has been deleted. 'Gapping', or what classical rhetoricians call zeugma, achieves relevance by reducing the processing effort. The contextual implicatures of the proposition are general. The contextual implication is that by desecularizing a portion of the dough offered as 'first-fruit' the whole lump is consecrated. The noun $\dot{\alpha} \pi \alpha \rho \chi \dot{\eta}$ has a wide array of weak implicatures. 'A $A \alpha \rho \chi \dot{\eta}$ is the metaphoric term. The wide array of implicatures alluded to range from the firstborn son (Ex 13:2,13;22:29), the first-fruits of the harvest (Lev 23:10), to the heaveoffering of dough as first-fruit (Num 15:19-20), Christ as first fruit (1Cor 15:20 and 23) and Christ as the first-born of many brethren (Rm 8:29).

Paul wishing to achieve optimal relevance introduces a synonymous parallelism in sentence 400 to reduce the readers processing effort: 'If the root is holy, then also the branches'. The significance of the saying is that if the 'root' is desecularised, then the branches are also consecrated. The root as vehicle of a submerged metaphor refers to the beginnings of Israel. In Romans 9:3-5 this reference goes back to the calling of the patriarchs, the covenant privileges and promises. The tenor of the vehicle may very likely include reference to the suffering righteous one, with contextual support in Romans 15:1-6 and 1Cor 16:15. In fact the suffering righteous one is the embodiment of the covenant with Israel. More particularly, one might find contextual implicatures in reference to 'the fathers' in Rm 11:28. This context may be extended to include 'a remnant' in Romans 11:5 and 'the elect' in Romans 11:7b. All these tenors are weakly implicated by Paul. Suffice to say the principal tenor of the allegory refers to the divine call manifest in Jewish allegiance to the covenant. Privileges of the covenant extend to the Gentile mission. Election to the divine covenant consecrates the mission to the Gentiles. 
In paragraph 4.11 above we indicated that Paul reinterpreted Israel in Romans 9:613 in eschatological terms with reference to the promises of God. In Romans 11:1-32 Paul's language becomes 'ostensively inferential' inasmuch as he deals with the problem of the rejection by Israel in a different way. Dinkler (1956:116) argues that Paul assigns a role to historical Israel which continues to exist as an inherent part of the history of salvation. It is clear that Paul provides an ostensive inferential perspective to the 'remnant', in paragraph 4.14 above. Dinkler rightly acknowledges that this 'continuing role of Israel', even as remnant, overlaps with the historical Israel although it is not identical with Israel. Dinkler summarizes his position as follows:

Paul in chapter 9 refers the promise and prerogative to the spiritualeschatological 'Israel', and in chapter 11 he doubtless acknowledges the prerogative of the historical people of Israel, i.e., the historical Israel denoted as God's people in a special way.

To recognize Paul's 'ostensive inferential' interpretation of Israel in chapter 11:16-24 one has to appreciate the difference between chapter 9 and chapter 11. In chapter 9:613 Paul deals with the problem of the discontinuity by reinterpreting the notion of Israel as the eschatological destiny of faithful humanity. In chapter 11 Paul recognizes the continuity of historical Israel, albeit as remnant, in the future destiny of faithful humanity. The destiny of faithful humanity particularizes in eschatological Israel. Dinkler (1956:116) qualifies the notion of 'prerogative'. The only prerogative Israel ever possessed was one of historical priority. Jewett (1985:345) contends that Paul insisted on the priority of Israel. His insistence of the priority of Israel, Jewett argues, must be understood within the context of his 'struggle for unity between Jewish and gentile Christians'. The privileges of her election consist in the fact that she was chosen to serve. The process of election defines and identifies the eschatological servant of Yahweh. The wide array of weak implicatures increase the potential implicatures of interpretation. Sperber \& Wilson (1986:236) observe that 'The wider the range of potential implicatures and the greater the hearer's responsibility for constructing them, the more poetic the effect'. The greater the poetic effect the greater the relevance of the imagery.

The nouns $\dot{\alpha} \pi \alpha \rho \chi \dot{\eta}$ and $\dot{\rho} i \zeta \alpha$ are vehicles referring to 'the righteous one/servant' as submerged vehicle. The tenor implicates 'the fathers', 'Israel', 'the remnant', and 'the resurrected Lord' as the righteous servant of God. Semantic features such as (elect) (faithfulness) (obedience) (righteousness) (justification) (humbleness) are a wide array 
of weak implicatures of the righteous servant. These features are now attributed to the Gentile Christians. This happens not of their own doing but because Gentile Christians are portrayed as being rooted in the promises of the true Israel. Jewett (1985:345) comments that the covenant promises and even the law are not abrogated, because if they were: 'the justification and the inclusion of the Gentiles lose their foundation'. The metaphoric terms 'first fruit', 'piece of dough as first fruit' and 'root' refer to the covenant promises of God. The ostensive inferential use of imagery makes the continuity between 'covenant elect' and the Gentile mission apparent as set out in par.4.13 above. These characteristics were not automatically accepted and implemented. The diatribe persuasively prepared the Gentile Christians to grow together into a calling to suffering righteousness. The Gentile Christians are via the root consecrated as covenant elect. The election privileges, discussed in par. 4.16 above, are transferred to the Gentile Christian communities which continue to fulfil the promises of the covenant election. In sentence 401.2 Paul particularises the reference:

In sentence 401 Paul directs his appeal to the second person singular pronoun su. Sentence 401 is a conditional of the type which Sperber and Wilson (1986:99) designate as a disjunctive modus ponens. The elimination rule may be represented as follows:

\begin{tabular}{|l|l|}
\hline \multicolumn{2}{||l|}{ DIAGRAM 6: DISJUNCTIVE MODUS PONENS } \\
\hline A Input & $\begin{array}{l}\text { (1) (If }(P \text { or } Q) \text { then } R) \\
\text { (11) } P\end{array}$ \\
\hline P Output & $R$ \\
\hline
\end{tabular}

The three protases, sentence $401.1-3$, follow in a causal sequence. The 'input' is contained by the protases. The apodasis contains the 'output':

(Input)

Protases: a. But if some of the branches were broken off,

b. and you, a wild olive shoot, were grafted in their place,

c. to share the rich root of the olive tree

(Output)

apodasis: do not boast yourself over the branches. 
The relations between the two protases are causal. Protasis c expresses the purpose of $\mathrm{b}$; b, again, is the result of a. The apodosis admonishes Gentile Christians that, in view of their being grafted in among the branches, they may not boast over the branches. This gesture is a commissive speech-act which encourages self-restraint.

In the relationship of identification between the pronoun $\sigma \dot{v}$, in sentence 401.2, and $\dot{\alpha} \gamma \rho\left\llcorner\hat{\imath} \lambda \alpha \iota \varsigma^{\circ}\right.$ semantic features such as (uselessness) (bitter) (wild) (wastefulness) are transferred to the pronoun $\sigma \dot{v}$. God circumvents this futile existence by grafting the wild olive shoot onto the cultivated olive. The cultivated olive derives its fruitfulness from the grace imparted by the calling of God. It is the root that consecrates the fruit. Although the wild olive has no merit in itself, it becomes fruitful by tapping nourishment from the rich root of the cultivated olive. The root refers to Gods promises given in a covenant to the Jews. It acknowledges the Jewish origins and guarantees the continuity of covenant election.

The reversal of horticultural practice makes $\dot{\rho} i \zeta \alpha$ an 'ostensive inferential' meta-

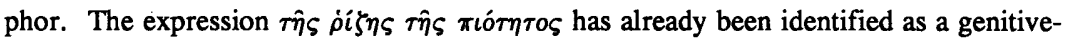
link metaphor. The 'third term C' of the metaphor: $\tau \hat{\eta} \varsigma$ ז tures from the context of verse $7 \mathrm{~b}$ to the metaphoric term B, that is $\tau \hat{\eta} \varsigma \dot{\rho} i \zeta \eta \bar{\zeta}$. The riches of the plant, or the sap, which is the substance of nourishment, refer to the elec-

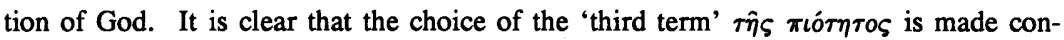
sistent with the principle of relevance to reduce the processing effort. A relevance analysis will concur with the comments of Michel (1966:276):

die Fettigkeit der 'Wurzel' in der Erwälung, die den Erzvätern zuteil wurde, und die die gleiche ist wie die unsrige.

The faithful community is desecularized from the Gentile environment and 'rooted' in

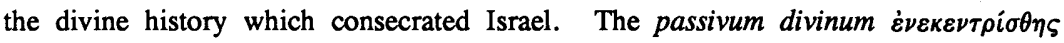
provides contextual support to the assumption of divine election which befell the Gentile recipients. The change in mutual cognitive environment consist in the following knowledge that dawns upon the Jewish Christians and the Gentile Christians alike. The Jewish Christians realize that the remnant theology (par. 4.14 above) is extended to include Gentile believers, Romans 9:25b-26:

Those who were not my people I will call 'my people', and her who was not beloved I will call 'beloved'. And in the very place where it was said to them, 'You are not my people', there they shall be called children of the living God. 
Gentile Christians who understand the remnant theology of Paul recognize the significance of the inclusive language usage. Remnant theology makes the Gentile converts realize that they are the 'objects of mercy, which he has prepared beforehand for glory', attested in Romans 9:23. In syntagmatic equivalent positions to 'my people' and 'beloved', in Romans 9:25, and 'children of the living God' in Romans 9:26, the Gentile converts are called 'a remnant' in Romans 9:27 and 'survivors' in Romans 9: 29.

27 ...: Though the number of the children of Israel were like the sand of the sea, only a remnant of them will be saved; 28 ...' 29 And as Isaiah predicted: 'If the Lord of hosts had not left survivors to us, we would have fared like Sodom and been make like Gomorrah'.

In the mutual cognitive environment of Jewish and Gentile believers the gentile Christians have become servants of Yahweh. They are both 'servants' and 'objects of mercy' ( $R m$ 9:23) by virtue of their righteousness. In Romans 9:30 Paul elaborates:

Gentiles, who did not strive for righteousness, have attained it, that is, righteousness through faith.

The metaphor calls for the recognition of grace among the recipients of the promise. Gentiles gained access to grace without works of the law. They had no virtue in themselves. They obtained righteousness by unconditional grace of God alone. They found Yahweh although they did not seek God ( $\mathrm{Rm} 10: 20)$. Ostensive inferential imagery attributes notions of covenant elect, remnant and righteousness to the Gentile Christian community. Inclusive language of Paul embraces the Gentile believers as 'a remnant chosen by grace', Romans 11:5. The faithful among the Gentiles are reckoned with the 7000 of Romans 11:4 'who have not bowed the knee to Baal'. Contextual implications attribute the continuity of Jewish privileges to the Christian community. Gaston (1982:417) contrasts Romans 9 and Romans 11 very aptly. He contends that if Romans 9:22 and 23 contrast 'objects of wrath' and 'objects of mercy' Romans 11 says that God changes the first into the second. A complete reversal of values take place. Ostensive inferential language makes the reason clearly manifest. The relationship between Judaism and the Christian communities is one of promise and fulfilment. The Gentile Christian communities complete Israel.

The recognition of grace leads to the 'desirable thought' which the metaphor interprets. 


\subsubsection{The Desirable Thought}

In the apodasis of sentence 401 Paul admonishes the converts not to boast 'do not boast yourself over the branches'. This admonition expresses the desirable thought as interpreted by the metaphor. It follows the juxtaposition of group interests in the protasis of sentence 401.2-3: 'But if some of the branches were broken off, and you, a wild olive shoot, were grafted in their place ....' The protasis reflect a conflict of Jewish priority and Gentile ascendency as set out in par 4.15 above. The admonition changes the cognitive environment of the interlocutor. These contextual effects call for modesty, humility and self-restraint. Paul attempts to resolve the conflict by reminding both parties of the source they share in common. By changing their mutual cognitive environment Paul resolves the conflict. The grafted branches 'yield fruit' by grace of God alone. Implicatures of 'the righteous one' become stronger in the context. The semantic features expressing contextual implicatures may be articulated in such a wide array of 'attributive' characteristics as the following:

(divine election) (servant) (faithfulness) (humbleness) (modesty) (justification) (remnant) (exaltation) (redemption) (sanctification) (unconditional submissiveness).

Characteristics such as these are reminiscent of the mutual change in cognitive environment. Consistent with the principle of relevance, the chiasm in sentence $\mathbf{4 0 2 . 2}$ increases the poetic effect of the statement:

It is not you that support the root, but the root (supports) you.

Sentence 402 and 407: 'do not become proud' retroactively reinforces the admonishment in sentence 401: 'do not boast over the branches'. The wide array of contextual implications to follow includes the meritlessness of the recipients supported by the root. This is further compounded by the unconditional love of God in supporting the grafted shoot. The Gentile Christians are admonished not to claim any prerogative for themselves. Campbell (1981:35) remarks that the analogy of the branches is designed to remind the Gentile Christians that branches of themselves do not constitute a tree. Campbell continues that the presumption of superiority on the part of the Gentile Christians will lead to the same result as that which spelt disaster for the Jews in the first place. They too might be broken off ( $\mathrm{Rm} 11: 21-22)$. 
Consistent with the principle of relevance, Paul's utterances in verses 19 and 20 display highly structured poetic language. Parallelism makes way for strict coupling. The chiasmic antithesis, $A$, verb $\dot{\varepsilon} \xi \varepsilon \kappa \lambda \dot{\alpha} \sigma \theta \eta \sigma \alpha \nu B$, noun $\kappa \lambda \dot{\alpha} \delta o \iota B 1$, pronoun $\dot{\varepsilon} \gamma \dot{\omega}$ and $A l$, verb $\dot{\varepsilon} \gamma \kappa \varepsilon \tau \rho \iota \sigma \theta \hat{\omega}$, increases the poetic effect.

403 (19) you might argue:

403.1 'Branches were pruned away

403.2 that I might be grafted in'.

Paul uses the dialectics of diatribe to persuade the interlocutor into humble submissiveness. 'You might argue' engages the reader in the dialogue. The coupling antithetically contrasts the premises 'pruned away' and 'grafted in'. The antithesis contrasts God's ostracising of the unbelieving Jews and his welcoming of the faithful Gentile Christians. The statement in Sentence 403.2 alleges that the interlocutor presumptuously claims divine authorization for a privileged position she/he enjoys. 'Be that as it may', Paul rebuts in sentence 404. Paul's intentions to challenge become manifest. The antithetical coupling then continues:

405 Because of unbelief were they broken off, 406 but by faith only do you stand.

The greater the poetic effects, the greater the relevance. A wide array of contextual effects opens up. A substantial segment of Jews has fallen into unfaithfulness. The door has opened for Gentile Christians to share in the promise given by God to the patriarchs. Paul pre-empts Gentile Christian complacency. The poetic effects reduce the processing effort. The contextual implications of Paul's rebuttal are persuasive. Paul uses persuasive language convincing boastful Gentile Christians to become obedient and submissive. The function of the antithesis is to explain why some Jews were rejected and the Gentile Christians accepted. This antithesis is tantamount to a contrast of faith and unbelief. Pro-actively Paul dissuades the Gentile Christians from

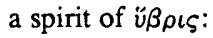

'Do not be proud but stand in awe'.

The contextual effect of the statement is that it was 'pride' that brought the Jews to their disaster in the first place. It is ironical that Paul uses the shame of Judaism, the fact that they fell into disrepute, to persuade the Gentile Christians not to be boastful. Campbell (1981:35) claims that Paul warns the Gentile Christians that the presumption 
of superiority will lead to the same fate as the unbelieving Jews. In fact, the 'root' and the cultivated olive has according to Longenecker (1989:100) an 'ethnic quality'. Getty (1989:457) captures the ostensiveness of Paul's imagery with his statement that Paul 'always links the salvation of the Gentiles with the ultimate salvation of the Jews'. This does not mean, Getty (1989:460) maintains that the Gentiles have to become Jews nor that the Jews must become Gentiles. Getty (1989:460) maintains that Paul's perspective is eschatological and his imagery apocalyptic. The imagery of the 'wild olive tree' is far from asserting that Israel must become part of the Church, Getty argues, that the Gentile Christians will be brought into Israel. The admonition in Verse 21 strengthens this view:

For if God did not spare the natural branches, perhaps he will not spare you.

The conflict of Jewish priority and Gentile ascendency emerges in the admonition of Gentile Christians. In the ensuing conflict the triad of servant, God and foe becomes apparent. The conflict spills over into a contrast of God's kindness and severity.

\subsubsection{The Kindness and Severity of God}

In sentences 410-414 we encounter two sets of logical entries that are contrasted and finally compared with each other. Sperber and Wilson (1986:86) define a logical entry as 'a set of deductive rules, each formally describing a set of input and output assumptions: that is, a set of premises and conclusions'.

The first set of logical entries referred to relates to assumptions of $\dot{\eta} \pi i \sigma \tau l \varsigma$, in sentence 406. This logical entry consists of input assumptions expressed by the text

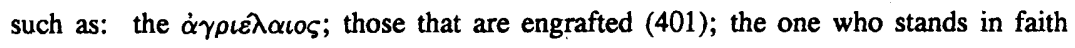
(406); who is not proud (407); who stands in awe (408) and who remains in the grace of God (412.1). Believers belonging to this logical entry enjoy the kindness $x \rho \eta \sigma \tau o ́ t \eta \varsigma$ (412) of God. The logical entry composing the unfaithfulness of Judaism contrast this entry.

The logical entry of 'disobedient Jews' portrayed as branches pruned out contrast the imagery of faithfulness above. The contrasting entry consists of input assumptions

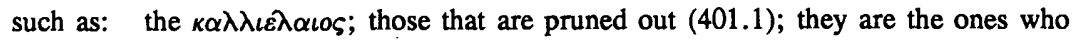
have fallen $\pi \varepsilon \sigma o \delta \tau \alpha \varsigma$ (411); they are implicated as prideful (407); they are disobedient $\hat{r} \hat{\alpha} \dot{\alpha} \iota \sigma \tau i \alpha(405)$ and, as a result, they are not spared by God. This is a logical entry

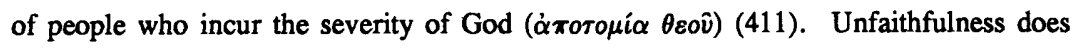
not jeopardise God's plan of salvation. The disobedience of the Jews provide the inventio, the occasion, which gives rise to the Gentile mission. The contextual implica- 
tions are also juxtaposed. Disobedience leads, in malem partem, to God pruning away. Obedience leads, in bonam partem, to God grafting the believer into the cultivated root.

The two logical entries may also be compared with one another as verse 24 shows:

For if you have been cut from what is by nature a wild olive tree and grafted, contrary to nature, into a cultivated olive tree, how much more will these natural branches be grafted back into their own olive tree.

The apodasis states the consequence of the condition in the protasis in sentence 414.12. The contextual implication is that God, by grace, may change the destiny of faithful Jews as much as He is able to change the lives and destiny of Gentile Christians.

The wide array of weak implicatures contrasts the status of both the Jews and the Gentiles. The faithful Jews were 'rooted' in the promise and grace of divine calling. The status of true Israel is that of servant! In the allegory, responsibility for the promise of Yahweh is henceforth shared with the Gentile Christians. A transformation of cognitive perceptions becomes inevitable. 'Responsibility for' does not mean 'prerogative of salvation'. Israel never possessed any prerogative. At stake is a prerogative of 'suffering servitude'. What is ostensively communicated by the allegory?

The allegory transforms the purity maps of people, places and values. The Gospel shares the privilege of promise and servitude with the Gentiles. Here Paul is sharing something of himself. Once Paul himself was proud. But if Damascus could transform Paul, the mutual cognitive environment of Jewish and Gentile Christians cannot remain the same. The imagery of the wild olive tree shares the privileges of the promise with Jews and Gentiles alike. 'To the Jews first and then also to the Greek' in effect means for Paul 'to the Jew first as much as to the Greek' ( $R m$ 1;16, 2:9 and 10, among other references). Faithful Jews and Gentiles now share a common root. The first fruit consecrates the lump. The root sanctifies the shoot. The reconciliation of Jewish and Gentile Christians are complete. Paul resolves any conflict by changing the mutual cognitive environment of Jewish and Gentile Christian alike. Jewish and Gentile Christians jointly compose the remnant of Yahweh. Jewish and Gentile Christians jointly share in the calling of eschatological Israel.

The nostalgia of a past promise to the patriarchs is replaced by knowledge of hope and fulfilment. Accomplishment brings joy. The imagery of 'rootedness' implies that Gentiles are not only recipients of salvation but have become participants or benefactors of Grace. The transformation takes place in mutual cognitive recognition. The change 
embraces even the reader. The wild and cultivated olive branches are united in the root. The nourishment of the cultivated olive is not abolished, it is shared. If the root is not rendered obsolete it is only because the promise of the root is fulfilled. Here ostensive inferential allegory is at its best. Promise and reconciliation are fulfilled in a change of mutual cognitive environment. The change in mutual cognitive environment brings a contextual awareness of service and mission. Participants are mutual cognisant of their mutual allegiance to God. Although the change in mutual cognitive environment will never be complete, yet we may know it has been achieved. The accomplishment of God's kindness becomes ostensive inasmuch as Jews and Gentiles have jointly become benefactors of grace and salvation.

\subsection{Conclusion}

Conclusively, it becomes clearer in relevance theory why Paul had decided in favour of the 'wild olive' tree and refrained from using the more frequently used 'vine' tree for his allegory. The choice of the 'wild olive' grafted onto the cultivated olive (true Israel) more vividly portrays the conversion of the Gentile Christians. The imagery also facilitates the participation of Gentile Christians in the continuity of eschatological Israel. A portrayal of the universal reconciliation of the Gentiles with vineyard imagery would require a laborious if not impossible processing effort. The wild olive branch imagery contributes to the relevance of the imagery required by reducing this processing effort. The grafting of the wild olive shoot into the cultivated olive root makes the imagery relevant for both the Gentile mission and the continuity of Israel. The imagery makes the reconciliation of Jewish Christians and Gentile Christians complete.

Paragraph 4.2 illustrated the contribution of relevance theory for the interpretation of Romans 11:16-24. Relevance theory accounts adequately for the contravention of horticultural conventions. By changing the reader's cognitive environment with persuasive diatribe, Paul achieves the relevance of the dialogue. The optimal relevance of a mutual change of cognitive environment becomes manifest in contextual effects and implications.

The imagery of the wild olive shoots grafted onto the cultivated root guarantees the continuity of divine promises (in par 4.11 above). The promises are founded in the election privileges articulated by Romans 9:3-5 in (par.4.13 above). God is faithful to his promises notwithstanding the failure of historical Israel and reluctance of 'objects of his wrath', (in par. 4.12 above). Gaston (1982:417) comments aptly that God would much rather have preferred to use the good olive branches as his instruments of his mercy. Since they would not participate he had to make do with wild olive shoots as instruments of mercy. The Gentile communities of Paul were 'instruments of his 
mercy'. Paul manages to reconcile the sanctity of the Gentile mission (par 4.14 above) with the continuity of Israel (par 4.13). The Jewish Christian and Gentile Christian conflict (par 4.15) is resolved in the destiny of eschatological Israel. The Gospel is the history of promises which leads to the destiny of faithful humanity. The covenant of election becomes complete in the Gentile mission. Optimal relevance culminates in the Gentile Christian communities which become identified with the calling and plight of suffering righteous one.

This article and the previous article provide an overview of semiotic hermeneutics in the ongoing literary critical dialogue of the twentieth century. The changing historical conditions of the twentieth century provide the exegete with variegated truth-perspectives of literary interpretation. By subsequently analysing the results of different readings of Romans 11:16-24, the possibility of methodological pluralism was avoided. Multiplying the reading process to include a formal analysis, a reader's response analysis, and a perspective from the pragmatics of relevance theory prevented us from slipping into one-dimensional consciousness of the meaning of the text. We allowed our knowledge of the meaning of Romans 11:16-24 to spiral its way through the changing historical conditions of our times. It is apparent that Peirce's 'final interpretant' manifests a process of endless semiosis (Lacan). The multiplication of representations of the interpretamen leads to the polymorphous character of the interpretant. The hermeneutic of literary critical dialogue provided a multiplicity effect in the reading and re-reading of the text and achieved relevance thereby.

Moreover, relevance theory is contingent upon changing historical conditions. Relevant though ostensive inferential semiotics may be, changing historical conditions will render its interpretation relative. A critical awareness of the changing historical conditions of our time prevents the exegete from conducting his/her enquiry in an act of $\ddot{u} \beta \rho \iota \varsigma$. Relevance theory offers the exegete some consolation. Relative though our interpretation may be, the change in mutual cognitive environment guarantees the relevance of our discourse.

\section{Endnotes}

1 Sperber and Wilson (1986:3) define a 'code' as 'a system' which pairs messages with signals, enabling two information-processing devices (organisms or machines) to communicate'. By 'message' Sperber and Wilson (1994:4) mean 'a representation internal to the communicating devices'. A 'signal', again, is a modification of the external environment which may or which can be produced by one device and recognised by the other.

2 A semantic representation of a sentence deals with a "common core of meaning shared by every utterance of it'.

3 Sperber and Wilsen (1986:46) define 'cognitive environment' as 'a set of assumptions which the individual is capable of mentaliy representing and accepting as true'. 


\section{Works consulted}

Aageson, J W 1986. Scripture and structure in the development of the argument in Romans 9-11. CBQ 48, 265-289.

1987. Typology, correspondence, and the application of scripture in Romans

9-11. Journal for the Study of the New Testament 31, 51-72.

Boers, H 1981. The problem of Jews and Gentiles in the macro-structure of Romans. Neotestamentica 15, 1981:1-11.

Bechtler, S R 1994. Christ. The telos of the law: The goal of Romans 10:4. CBQ 56, 288-308.

Campbell, W S 1981. The freedom and faithfulness of God in relation to Israel. Journal for the Study of the New Testament 13, 27-45.

Cole, P \& Morgan, J 1975. Syntax and semantics 3: Speech acts. New York: Academic Press.

Cranford, M 1993. Election and ethnicity: Paul's view of Israel in Romans 9:1-13, Journal for the Study of the New Testament 50, 27-41.

Davies, W D 1977. Paul and the people of Israel. NTS 24, 4-39.

De Villiers, J L 1981. The salvation of Israel according to Romans 9-11. Neotestamentica 15, 1981:199-221.

Dinkler, E 1956. The historical and the eschatological Israel in Romans chapters 9-11:

A contribution to the problem of predestination and individual responsibility. Journal of Religion 36, 109-127.

Epp, E J 1986. Jewish-Gentile continuity in Paul: Torah and/or faith? ( $R \mathrm{~m}: 1-5)$. Harvard Theological Review 79:1-3, 80-90.

Fink, C F 1968. Some conceptual difficulties in the theory of social conflict. Journal of Conflict Resolution 12/1, 412-460.

Gaston, L 1982. Israel's enemies in Pauline theology. NTS 28, 400-423.

Getty, M A 1989. Paul and the salvation of Israel: A perspective on Romans 9-11. Journal for the Study of the New Testament 36, 456-469.

Grice, H P 1975. Logic and conversation, in Cole 1975:41-58. 1978. Further notes on logic and conversation, in Cole 1975:113-28.

Guerra, A J 1990. Romans: Paul's purpose and audience with special attention to Romans 9-11. Revue Biblique, 219-237.

Hartshorne, C \& Weiss, P (eds) 1974. Collected papers of Charles Sanders Peirce.

Volumes 1 \& 2. Cambridge, Massachusetts: The Belknap Press of Harvard University Press.

Jakobson, R 1960. Concluding statement: Linguistics and poetics, in Sebeok TA (ed), Style in language, 350-377. Cambridge. Massachusetts: MIT Press. 
Jakobson, R 1966. Grammatical prallelism and its Russian facet. Language 42, 399429.

Jauss, H R 1984. Ästhetische Erfahrung und literarische Hermeneutik. Frankfurt: Suhrkamp.

Jewett, R 1985. The law and the coexistence of Jews and Gentiles in Romans. Interp $39,341-356$.

Katz, J J \& Fodor J A 1963. The structure of a semantic theory. Language 39, 170210.

- 1972. Semantic theory. New York: Harper and Row.

Lenski, G E 1954. Status christallization: A non-vertical dimension of social status. American Sociological Review 19, 5-13..

1966. Power and privilege: A theory of social stratification. New York: McGraw-Hill.

Levin, S R 1969. Linguistic structures in poetry. The Hague: Mouton.

Longenecker, B W 1989. Different answers to different issues: Israel, the Gentiles and salvation history in Romans 9-11. Journal for the Study of the New Testament 36, 95-123.

Mey, J L 1994. Pragmatics: An Introduction. Oxford: Blackwell Publishers.

Peirce, C S 1974. Elements of Logic, in Hartshorne \& Weiss, 1974: Volume 2.

Rauche, G A 1983. The dynamics of philosophical argument. Durban: The Institute for Social and Economic Research, report no. 16, University of Durban-Westville.

- 1985. Theory and practice in philosophical argument. Durban: Institute for Social and Economic Research, University of Durban-Westville.

Rese, M 1990. Church and Israel in the deuteropauline letters. Scottish Journal of Theology 43, 19-32.

Schiffrin, D 1994. Approches to Discourse. Oxford: Blackwell Publishers.

Schwarz, D S 1977. On pragmatic presupposition. Linguistics and Philosophy 1, 2, 247-258.

Searle, J 1977a. The philosophy of language. Oxford Univesity Press.

_ 1977b. What is a speech act? in Searle 1980:39-53.

- 1979a. The classification of illocutionary acts, in Searle 1979b: 1-29.

- 1979b. Expression and meaning. Cambridge, Cambridge University Press.

Searle, K, Kiefer, F \& Bierwisch M (eds) 1980. Speech act theory and pragmatics. Dortrecht: Reidel.

Sperber, D \& Wilson, D 1986. Relevance: Communication and Cognition. Oxford: Basil Blackwell.

Walters, J C 1993. Ethnic issues in Paul's letter to the Romans: Changing selfdefinitions in earliest Roman Christianity. Pennsylvania: Trinity Press International. 